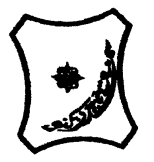

Bayero Journal of Pure and Applied Sciences, 10(2): 64 - 68

Received: June, 2016

Accepted: June, 2017

ISSN $2006-6996$

\title{
AN ASSESSMENT OF POLLUTION IN AQUATIC ENVIRONMENT USING BIOINDICATORS: A REVIEW
}

\author{
${ }^{1 *}$ Abdullahi, U.A. and ${ }^{2}$ Ibrahim, S. \\ 1, 2 Department of Biological Sciences, Bayero University, Kano, P.M.B 3011, Kano, Nigeria \\ ${ }^{1 *}$ Corresponding Author: abdullahiubaahmed@gmail.com, auahmed.bio@buk.edu.ng GSM: 08068200148
}

\begin{abstract}
This review highlights the importance of biological indicators in monitoring presence of pollution in aquatic environment. This assessment involves the use of living organisms (macro or microorganisms and plants or animals) as bioindicators of pollution in water bodies. These organisms are believed to show higher sensitivity to pollution than the best chemical indicators. Bioindicators or test of relevance to water study includes; test based on Chlorella vulgaris, Daphnia magna straus, test Spirotox, Microtox, using macroinvertebrates, algae and vertebrates (such as fishes). Variety of biotic indices based on macroinvertebrates community as indicators have been highlighted which includes: Microinvertebrate Biotic Index (MBI), Extended Trend Biotic index (ETBi), Belgian Biotic index (BBi), Rapid Bioassessment Protocols (RBPs), Biological Monitoring Water Quality (BMWQ) and Family level Biotic Index (FBI). Based on Microinvertebrate Biotic Index (MBI), grading of water quality alone with the taxonomic group of macroinvertebrate was divided into grade $I, I I, I I I, I V$ and $V$ representing clean water, mildly, moderately, highly and severely polluted water with the tolerance rating of 2, 4, 6, 8 and 10 respectively. The review emphasized the need for the use of bioindicators in detecting water pollution, because bioindicators are much more sensitive than the best chemical indicators.
\end{abstract}

Keywords; aquatic environment, bioassessment, bioindicators, pollutant, tolerance rating

\section{INTRODUCTION}

Pollution is a special case of habitat destruction, which occurs in all habitats; land, sea, fresh water and even in the atmosphere. As in the word of Alina (2015), pollution takes place when the environment (aquatic or otherwise) cannot process or neutralize harmful byproducts in due course without any structural or functional damage to its system. In other words, an environment is typically referred to as polluted when it is impaired by anthropogenic contaminants and either does not support human activities (such as drinking, fishing) or undergoes a marked shift in the ability to support its constituent biota communities such as fishes (Singh and Konkan, 2014). Therefore, to safeguard our natural environment from the disaster of pollution, routine assessment of the environment becomes necessary. There are therefore different ways or methods of pollution assessment in an environment, these includes; chemical assessment method which involves the assessment of "chemical load" in an environment. Chemicals at low concentration have a variety of toxic actions which produces different toxic effects. But at high concentrations, chemicals show one common effect, that is they cause death of the experimental organism. Tests are therefore carried out on each chemical to obtain a concentration-response relationship so that the limiting amount of polluting substance which causes death can be calculated (Lloyd, 1992). Other form of pollution assessment method is by taking the physical characteristics of the environment. However, the use of biological assessment provides the most ideal way of evaluating the impact of pollution in an environment.

Assessment therefore, refers to the use of biological entity as a detector and its responses as a measure to determine environmental conditions of an environment (Mengzhen et al., 2013). In an aquatic environment, it involves evaluation of the biological condition of water body with the use of biological surveys and other direct measurements of resident biota in surface water (Mengzhen et al., 2013).

Bioassessment of aquatic pollution typically looks at the assemblage of organisms such as periphytons, benthic macroinvertebrates, fishes, amphibians, reptiles, birds and vegetations in the water body. Thus, these organisms used as bioindicators are characterized by much higher sensitivity than the best chemical indicators. Aquatic organisms accumulating pollutants allow us to detect them even when their water concentrations are too low to be detected (Mengzhen et al., 2013).

Tests/Bioindicators Used in the Analyses of Water and Sewage Toxicity

Test Based on Chlorella vulgaris

These are unicellular green algae, widespread in fresh waters. Diluted sewage solutions are introduced into laboratory algal cultures of this specie, and then absorbance is measured with a spectrophotometer in the visible range (Nałęcz-jawecki and Sawicki, 1998). Adam et al. (2009) reported the use of $C$. vulgaris to evaluate the toxicity of 1-alkyl-3-methylimidazolium ionic liquid (ILs) in fresh water and brackish environments. 
He expressed toxicities toward the algae ( $C$. vulgaris) as $\mathrm{EC}_{50}$ values which shows that a distinct relationship exists between alkyl chain and toxicity: in which in nearly all cases, a two-carbon increase in chain length results in $E_{50}$ falling by nearly one order of magnitude. Pham et al. (2008) however, reported that the length of alkyl chain in the cation of imidazolium and pyridinium ILs has a direct influence on the photosynthetic response of many algae including $C$. vulgaris. The cited results clearly demonstrate the wide diversity of responses of algae exposed to various ILs, which are due not only to the different sensitivities of algal organism but also to the complexities of the chemical structures of ILs; where alkyl chain length, the various functional groups, cationic head groups and the types of anions are active variables as far as the mode of toxic action are concerned.

\section{Test Based on Daphnia magna Straus}

This is a crustacean living in fresh waters, it is the most commonly used zooplankton in toxicological tests in wastewater treatment, due to short doubling time, high sensitivity, and simplicity; therefore, it has been used as indicator in various study (APHA, AWWA, WEF, 1992; Official Gazette, 1996; USEPA, 2002). Young organisms are placed in crystallizers with sewage solutions of different concentrations. The count of bioindicators showing the test effect (organism immobilization) is determined after 24 and 48 hours. These data allow determining sample toxicity (Nałęcz-jawecki and Sawicki, 1998). Villegas et al. (1999) reported the use of $D$. magna as a toxicity indicator for textile industrial effluents in Mexico, this shows that, the toxicity tests combined with physicochemical analysis are essential in the evaluation of effluent quality and also in the assessment of treatment plant efficiency. Movahedian et al. (2005) evaluated the acute toxicity of the effluents from different units of Isfahan (Iran) wastewater treatment plant using this organism. The immobility of Daphnia specie was determined after 48 hours and the toxicity results showed that $48 \mathrm{~h}-\mathrm{LC}_{50}$ for raw wastewater was 30\% (v/v).

Test Spirotox

Spirotox is a short-term or acute toxicity test that is based on ciliated Protozoan Spirotostomum ambiguum, present in clean rivers and lakes. The principle behind the test is that, ciliates are placed in the sample and observed under slight magnification.
The cells of these very sensitive organisms undergo dissolution (lysis) when affected by toxicants. Sample toxicity is determined by its dilution, causing lysis of $50 \%$ of the population (Nałęcz-jawecki and Sawicki, 1998). Test spirotox was found to be very sensitive to heavy metals, fungicides and pharmaceuticals used to cure diseases of the human nervous system (Nałęczjawecki , 2004). He also revealed that Spirotox was used for analysis of Cyanobacterial bloom. He further stated that, although, the organism is moderately sensitive to hepatotoxins, the test seems to be a good tool for evaluation of entire toxicity of a blooms. Spirotox test was also applied to evaluate the toxicity of extract from medical devices (Nałęcz-jawecki, 2004). Further review shows that, test spirotox was used as part of a new tool for testing the toxicity of volatile compounds (Nałęcz and Sawicki, 1999).

\section{Test Microtox}

This consists of measurement of the natural luminescence of bacteria Vibrio fischeri, suspended in the solution of the sample to be analyzed. Toxic chemical compounds inhibit the activity of bacterial enzymes, which reduces the intensity of luminescence. The measurement is performed by spectrophotometric method (Ren, 2004).

\section{Test Using Macroinvertebrates}

This involves the use of various methods, including the most common practice of macroinvertebrate community-level diversity indices, such as taxa richness and abundance of macroinvertebrates; and multi-metric indices of different macroinvertebrate taxa and multi-environmental factors (Resh, 1995; Gheteu and Costin, 2011). A great variety of biotic indices and scores based on macroinvertebrates community as indicators have been developed and applied for water quality assessment, which includes: Macroinvertebrate Biotic Index (MBI) (Maiti, 2004), Extended Trent Biotic index (ETBi) (Chandler, 1970), Belgian Biotic index (BBi) (De Pauw and Vanhooren, 1983), Rapid Bioassessment Protocols (RBPs) (Barbour et al., 1999), Biological Monitoring Water Quality (BMWQ) (Camargo and Mufioz, 1993), and the Family-level Biotic Index (FBI) (Hilsenhoff, 1988).

These indices are tools developed to assess the degree and extent of wastewater discharge into aquatic ecosystems. The MBI for example is an average of tolerance rating weighted by macroinvertebrates abundance at each stream section, and is calculated from the formula:

$$
M B I=\sum_{i=1}^{n}(\mathrm{niti}) / \mathrm{N}
$$

Where, $\mathrm{n}_{\mathrm{i}}=$ number of individuals in each taxon $\mathrm{i}$;

$t_{i}=$ tolerance rating assigned to that taxon $i$;

$\mathrm{N}=$ total number of individuals in the sediment sample (Maiti, 2004).

The summary of some tolerance rating in accordance with taxonomic group of some macroinvertebrates and water quality status are illustrated in Table 1 below: 
Bajopas Volume 10 Number 2 December, 2017

Table 1: Tolerance Rating According to Taxonomic Group and Water Quality Grade

\begin{tabular}{|c|c|c|}
\hline $\begin{array}{c}\text { Quality of } \\
\text { water }\end{array}$ & Taxonomic Group & $\begin{array}{c}\text { Tolerance } \\
\text { Rating }\end{array}$ \\
\hline $\begin{array}{l}\text { Clean water } \\
\text { (Class-I) }\end{array}$ & $\begin{array}{l}\text { Stonefly (Plecoptera): Baetis, Brachytera, Mayfly(Ephemeroptera), Caddisfly } \\
\text { larvae (Trichoptera): Caddis hydropsyche, } \\
\text { C. calimnophilus }\end{array}$ & 2 \\
\hline $\begin{array}{l}\text { Mild Pollution } \\
\text { (Class-II) }\end{array}$ & Dragonfly (Odonata) & 4 \\
\hline $\begin{array}{l}\text { Moderately } \\
\text { Polluted } \\
\text { (Class-III) }\end{array}$ & $\begin{array}{l}\text { Prawn (Crustacean), Beetles (Coleoptera), Riffle beetle (Stenelmis, Elmidae); } \\
\text { Dineutus (Gyrinidae); Hydrophilus (Hydrophilidae); Dytiscus (dytiscidae). Bugs } \\
\text { (Hemiptera)- Lethocerus (Belostomidae); Notonecta (Notonectidae); Sigera } \\
\text { (Corixidae); Hydrometra (Hydrometridae); Gerris (Gerridae). }\end{array}$ & 6 \\
\hline $\begin{array}{l}\text { Highly } \\
\text { Polluted } \\
\text { (Class-IV) }\end{array}$ & Chironomus larvae (Chironomidae-Diptera), Mollusca & 8 \\
\hline
\end{tabular}

Severely Chironomus, Tubificidae (Tubifex sp.-sludge worm); Tubifera (Rat-tail maggot)

(Class-V)

Source: Maiti (2004)

\section{Test Using Algae}

Algae are the vital group of plants in aquatic ecosystem and are important components of biological indicators for monitoring and evaluation of water quality. They are suited in water quality assessment because of their nutrient needs, rapid reproduction rate and very short life cycle. Algae are valuable indicators of ecosystem conditions because they respond quickly to a wide range of water conditions due to change in water chemistry (WALPA, 2012). For example, increases in water acidity due to acid-forming chemicals that influence lake $\mathrm{pH}$ levels, as well as heavy metals discharged from industrial areas, affect the composition of genera that are able to tolerate these conditions. Maiti (2004) and Tahir et al. (2013) reviewed the importance of algae with regard to water quality studies as follows:

- Algae have wide temporal and spatial distribution and they are easier to detect and sample.
- That, presence of algae in drinking water supply or sources causes the problems of tastes and odours; impart coloration of water and degrades the palatability of water.

- Growth of algae in filter bed causes the hindrance of filter operation and degrades the palatability of water.

- Growth of algae in clariflocculator, reservour wall etc. is totally unwanted, and can be controlled by use of copper sulphate solution.

- Algae are also used as indicator of level of water pollution and respond quickly to the changes in the environment due to pollution.

- Algae serve as sources of oxygen supply for the bacterial oxidation of sewage and wastewater in oxidation pond.

The table below give a highlights of the aquatic environmental problems and associated algal type that causes the problem.

Table 2: Aquatic Environmental Problems and Possible Causative Algal Type

Environmental Problems Type of Algae

1. Taste and odour causing Pandorina, Volvox, Gomphosphaeria, Anabaena, Anacystis, Aphanizomenon, algae Hydrodictyon, Species of Synedra, Fragillaria.

2. Filter bed clogging algae Species of chlorella, Synedra, Oscillatoria, Spirogyra, Diatoms. Palmella, Anabaena, Rivularia, Anacystis.

3. Growth and reservour wall Cladophora, Tolypothrix, Chaetophora, Oedogonium, Lyngbya, Stigeoclonium, Ulathrix, Batrachospernum, Chara, Vaucheria, Draparnaldia, Rivularia

4. Indicator of water Phormidium, Anabaena, Euglena, Spirogyra, Chlorella, Gloeocapsa, pollution Stigeoclonium, Clamydomonas. Lyngbya, Oscillatoria, Chlorococcum, Spirulina etc are the indicators of organic pollution

5.Wastewater treatment pond Scenedesmus, Ankistrodesmus, Spirulina, Closteridium, Clamydomonas, algae

Source: Maiti (2004) Schizothrix, Cloterium, Chodatella, Chlosteriopsis.

\section{Test Using Fishes}

Fish have been used as bioindicators of water pollution for many years, this is in line with the species diversity, numbers and health status of fish in water. Fish constitute the last link of food chain, where they are directly affected by what is going on among producers (phytoplankton and higher plants) or lower consumers (zooplanktons, protozoan, and small crustaceans) (Lloyd, 1992).. Fish serve as valuable bioindicators for the fact that, it is relatively easy to determine their numbers, biological diversity and behaviors. 
Changes in water oxygen content for example increases turbidity or the presence of mineral compounds and toxic substances may result in their hyper-excitability, eyeball projection out of the eye socket, awkward swimming, laying upside-down, equilibrium disturbances, or even death (Lloyd, 1992). In such a case the state of the whole population deteriorates very quickly, but fish can also recover within a very short time. (Pickering and Sumpter, 2003). Review of the research conducted on fish of the family Salmonidae, revealed that, the species are characterized by having a narrow range of tolerance and high sensitivity, especially with regard to the water oxygen content and pollution level in water (Berecka et al., 2003). Numerous authors (Sprague, 1973; Gimeno et al., 1997 and Berecka et al., 2003) reported frequent developmental defects in fish, caused by the presence of chemical compounds affecting the organisms during sex differentiation. Some chemical compounds are characterized by estrogenic properties and disturb the endocrine functions of fish. An example may be Nonylphenol polyethoxylates (NPnEO) and products of their degradation. The studies performed on rainbow trout (Salmo gairdneri irideus) described the estrogenic activity of this group of compounds. Nonylphenol mimics the effects of natural estrogen - estradiol and binds to estrogen receptors, inducing vitellogenin synthesis in hematocytes. This disturbed natural steroid metabolism, has an adverse effect on spermiogenesis, and causes hermaphroditism in fish (the formation of intersex gonads) (Gimeno et al., 1997; Pickering and Sumpter, 2003). The presence of vitellogenin (specific protein contained in the egg yolk) in male fish indicates the presence of xenoestrogens in the environment. Another good candidate for toxicity evaluation according to

\section{REFERENCES}

Adam, L., Marcin, N. and Piotr, S. (2009): Toxicity of Imidazolium and Pyridinium Based Ionic Liquids Towards Algae. Chlorella vulgaris, Oocystis submarina (green algae) and Cyclotella meneghiniana, Skeletonema marinoi (diatoms). Green Chem., 580-588. doi: $10.1039 / b 821140$ j

Alina, B. (2015): Pollution Facts and Types. Live Science Contribution, Pp. 1-5.

APHA, AWWA, WEF (1992): Standard Methods for the Examination of Water and Wastewater. 20th ed. USA.

Barbour, M.T., Gerristen, B.D. and Snyder, B.D. (1999): Benthic Macroinvertebrate Protocols. In: Barbour, M.T., Gerristen, B.D., Snyder, B.D. and Stribling, J.B. (eds), Rapid Bioassessment Protocols for Use in Streams and Wadeable Rivers: Periphytons, Benthic Macroinvertebrates and Fish, EPA 841-B-99002. U.S. Environmental Protection Agency, Office of Water, Washington, DC: 7.1-7.2.

Berecka, B., Gadzała, K. R., Bartoszewicz, J. and Buszewski, B. (2003): The Determination of Nonphenol Polyethoxylates in the Environmental Samples Using Coupled international standards organizations, is a small, active tropical zebra fish (Brachydanio rerio) (Lloyd, 1992). This specie of fish is good for acute (short term) toxicity test. It has an advantage over rainbow trout for the fact that, it can breed all the year round in the laboratory and also because of its small size (smaller than rainbow trout), it requires less water and less space for the test to be carried out. In all, the concentration-response relationship are determined in which mortality have been accepted to be used as the common response of fish to chemical contaminants (Lloyd, 1992).

\section{Conclusion}

There are wide variety of chemical compounds in aquatic environments. And having considered the fact that aquatic environmental pollution poses a serious threat to the environment and as well as providing valuable information about the degradation of the ecosystem and dangers to human and animal health, it is beyond any doubt that the problem of toxicity of polluting substances in aquatic environment can best be monitored using biological assessment methods. These in combination with conventional chemical analysis will provide appropriate results or data that can best be used to interpret environmental changes as a result of pollution and ecological tolerance to pollution of a given ecosystem.

\section{Recommendation}

Diverse and complex nature of aquatic environment makes it difficult to assess its pollution using chemical analysis only. Hence, it is recommended that biological assessment using appropriate bioindicators should be employed most especially due to high sensitivity of living organisms to pollution and thus a true picture of the conditions in aquatic environment will be obtained.

Chromatography Techniques, Chem,. Anal. 48: 4-13.

Camargo, J. A. and Mufioz, H. (1993): Macrobenthic Surveys as a Valuable Tool for Assessing Freshwater Quality in the Iberian Peninsula. Environmental Monitoring and Assessment, 24:71-90.

Chandler, J. R., (1970): A Biological Approach to Water Quality Management. Water Pollution Control, 69: 415.

De Pauw, N. and Vanhooren, G. (1983): Method for Biological Quality Assessment of Water Courses in Belgium. Hydrobiologia, 100:153168. In: Mengzhen, X., Zhaoyin. W., Xuehua, D. and Baozhu, P. (2013): Effect of Pollution on Macroinvertebrates and Water Quality Bioassessment, Hydrologia-springer Science and Business Media Dordrecht, 5:113.

Gimeno, S., Komen, H., Vanderbosch, P.W.M. and Browmer, T. (1997): Disruption of Sexual Differentiation in Genetic Male Common Carp (Cyprinus carpio) Exposed to an Alkylphenol, During Different Life Stages. Environ. Sci. Technol., 31(10):2884-7. 
Gheteu, D. and Costin, H. (2011): Water Quality Assessment Using Benthic Macroinvertebrates in Wetlands and Ponds: Preliminary Study Case of Jijia and Miletin Ponds (ROSPA0042). Recent Researches in Environment, Energy Planning and Pollution, 8:111-114.

Hilsenhoff, W. L. (1988): Rapid Field Assessment of Organic Pollution with a Family-level Biotic Index. Journal of North American Benthological Society, 7:65-68.

Lloyd, R. (1992): Pollution and Fresh Water Fish, 1st edn. Blackwell Scientific Publications Inc. 3 Cambridge Centre Pp. 24-26.

Maiti, S.K. (2004): Hand Book of Methods in Environmental Studies, (Vol. 1 Water and Wastewater Analysis), 2nd Edn. ABD Publishers, B-46, Natraj, Imliwala Phatak, Jaipur-302 015 (Rajasthan) India Pp. 1-279.

Mengzhen, X., Zhaoyin W., Xuehua D. and Baozhu P. (2013): Effect of Pollution on Macroinvertebrates and Water Quality Bioassessment, Hydrologia- springer Science and Business Media Dordrecht, 5:1-13.

Movahedian, H., Bina, B. and Asghari, G.H. (2005): Toxicity Evaluation of Wastewater Treatment Plant Effluents Using Dapnia magna. Iranian J. Env. Health Sci. and Engn. 2(2):1-4.

Nałęcz-jawecki, G. and Sawicki, J. (1998): Toxicity of Inorganic Compounds in the Spirotox test A Miniaturized Version of the Spirostomum ambiguum test. Environ. Contam. Toxicol., 34:1-5.

Nałęcz-jawecki, G. and Sawicki, J. (1999): Spirotox- A new tool for testing the toxicity of volatile compounds. Chemosphere, 38(14): 32113218.

Nałęcz-jawecki, G. (2004): Spirotox- Spirostomum ambiguum acute toxicity test- 10 years of Experience. Environmental toxicology, 19:357-364, dio:10.1002/tox.20023.

Official Gazette (1996): Ordinance About Emission of Substances and Heat for Discharging of Effluents From Pollution Source. Ljubljana, 35: 2953-63.
Pham, T. P. T., Cho, C.W., Min., J. and Yun, Y.S. (2008): Response of Algae to the Alkyl Chain in the Cation of Imidozolium and Pyridinium Ionic Liquids. J. Biosci. Bioeng.,105: 425428.

Pickering, A.D. and Sumpter, J.P. (2003): Comprehending Endokrine Disturps in Aquatic Environments. Environ. Sci. Technol., 1: 331-136A.

Ren, S. (2004): Assessing Wastewater Toxicity to Activated Sludge: Recent Research and Developments. Environmental International, 30: 1151-1164.

Resh, V. H. (1995): Freshwater Benthic Macroinvertebrates and Rapid Assessment Procedures for Water Quality Monitoring in Developing and Newly Industrialized Countries. In: Davis, W. S. and Simon, T. P. (eds), Biological Assessment and Criteria. Lewis Publishers, Boca Raton: 167-177.

Singh, R. K. and Konkan, B. S. (2014): Special Issues on Aquatic Environment: A Review, International Journal of Environment and Wastewater Management, 15:1-5.

Sprague, J.B. (1973): The ABC's of Pollutant Bioassay Using Fish. In: Biological Methods for the Assessment of Water Quality (Ed. by Cairns, J.( Jnr.) and Dickson, K.L.), Pp. 6-30, ASTM STP 528. American Society for Testing and Materials, Philadelphia.

Tahir, A., Bulent, S., Mehmet, F.S., Mehmet, A., Turan, K. and Ozgur, C. (2013): Relationship of Algae to Water Pollution and Waste Water Treatment . Intech. 335-337.

USEPA (2002): Methods for Measuring the Acute Toxicity of Effluents and Receiving Waters to Fresh Water and Marine Organisms, EPA821-R-02-01.

Villegas, N. A., Gonzalez, M. C. and Lopez, E. (1999): Evaluation of Daphnia magna as Indicator of Toxicity and Treatment efficacy of Textile Wastewater. Environ. Int., 25(5): 619-24.

WALPA, (2012): Washington State Lake Protection Association, Nostoca Algae Laboratory Report, Karl Bruun, Bainbridge Island, Washington, D.C. US. 